\title{
Implementasi Konseling Eksistensial-Humanistik untuk Meningkatkan Self-Esteem pada Siswa Terisolir di Cirebon
}

\author{
Muzaki ${ }^{1}$, Siti Dila Nur Aldina ${ }^{2}$ \\ ${ }^{12}$ Program Studi Bimbingan Konseling Islam, Fakultas Ushuluddin Adab dan Dakwah, \\ IAIN Syekh Nurjati Cirebon \\ Email Penulis ${ }^{1}:$ kemalzaki66@gmail.com \\ Email Penulis ${ }^{2}$ : dila.nuradlina@gmail.com
}

\begin{abstract}
Abstrak
Siswa terisolir adalah suatu sikap individu yang tidak dapat menyerap dan menerima norma-norma ke dalam kepribadiannya dan juga tidak mampu untuk berperilaku yang pantas atau menyesuaikan diri menurut tuntutan lingkungan yang ada. Sehubungan itu karakteristik low self-esteem yaitu, ketidaksadaran diri, kurang percaya diri, takut mengambil resiko, mudah putus asa, pesimis, merasa kesepian dan terasingkan. Maka dibutuhkan peningkatan harga diri dengan memberdayakan, memberikan energi dan memotivasi, karena hal ini bisa terjadi kepada siapapun, termasuk kepada siswa terisolir. Dengan pendekatan yang terpusat pada manusia yaitu konseling eksistensialhumanistik tentunya diharapkan mampu mengatasi masalah yang dihadapi oleh siswa terisolir yang sering ada di sekolah-sekolah. Dalam penelitian ini, terdapat pembahasan metode konseling eksistensial-humanistik untuk meningkatkan self-essteem pada siswa terisolir yakni metode untuk meningkatan self-esteem pada siswa terisolir: dengan pemberian dukungan sosial (social support), intervensi cognitive-behavior, pemantapan fisik, strategi lainnya (konseling pendekatan eksistensial-humanistik). Implementasi konseling pendekatan eksitensial-humanistik: kesadaran diri, kecemasan, tanggung jawab dan penciptaan makna.
\end{abstract}

Kata Kunci: Konseling Eksistensial-Humanistik; Self-Esteem; Siswa.

\section{PENDAHULUAN}

Perkembangan usia individu akan mengalami perubahan baik yang menyangkut perkembangan fisik, perkembangan psikis ataupun perkembangan jasmani dan perkembangan rohani. Saat seorang individu memasuki tahap pendidikan Sekolah Menengah Atas (SMA), pada saat itulah individu memasuki masa remaja yang mana merupakan masa mencari jati diri, dan mencoba hal-hal baru yang belum ditemui sebelumnya. Masa remaja menurut Mappiare (1982) berlangsung antara umur 12 tahun sampai dengan 21 tahun bagi wanita, serta 13 tahun sampai dengan 22 tahun bagi pria (Ali \& Asrori, 2015). Lebih lanjut dikatakan bahwa perubahan tubuh yang tidak familier dan fisik yang baru harus terintergasi 
ke dalam pola fikir yang membentuk penghargaan diri dan relasi sosial atau hubungan sesamanya.

Pada tahap ini lingkungan sekolah akan mengembangkan pola pikir dan memperluas kehidupan sosial individu. Pusat aktifitas pada usia sekolah berhubungan dengan sekolahnya, tugas-tugas intelektual, hubungan dengan guru, teman, norma serta tuntutan sosial. Hubungan sosial individu berkembang karena adanya dorongan rasa ingin tahu terhadap segala sesuatu yang ada di dunia sekitarnya, hal ini menyangkut juga penyesuaian diri terhadap lingkungan, seperti makan dan minum, menaati peraturan, membangun komitmen bersama dalam kelompok atau organisasinya, dan sejenisnya.

Adanya siswa yang terisolir akan merujuk pada suatu keadaan dimana seseorang mengalami keterasingan, keterisolasian atau terpencil dari lingkungannya. Sementara apabila melihat tentang isolasi terbagi menjadi dua macam, yaitu voluntary isolate dan involuntary isolate. Voluntary isolate adalah suatu perbuatan yang menarik diri dari kelompok karena adanya rasa kurang memiliki minat untuk menjadi anggota suatu kelompok. Sementara itu, involuntary isolate adalah suatu keadaan dimana seseorang ditolak oleh kelompok dan sikap menolak terhadap orang lainatau sikap tertutup dalam kelompoknya meskipun dia ingin menjadi anggota kelompok tersebut. Involuntary yang subyektif beranggapan bahwa dia tidak dibutuhkan oleh kelompoknya dan menjauhkan diri dari kelompok, sedangkan involuntary yang obyektif sebaliknya dia benar-benar ditolak oleh kelompoknya (Mohammad Ali \& Mohammad Asrori, 2015).

Kebutuhan sosial siswa direfleksikan dalam keinginan untuk dikenal dimata teman sebaya, kebutuhan memiliki teman, dan keinginan untuk menarik dimata orang yang disukai. Anak terisolasi adalah suatu sikap individu yang tidak dapat meyerap dan menerima normanorma ke dalam kepribadiannya dan ia juga tidak mampu untuk berperilaku yang pantas atau menyesuaikan diri menurut tuntutan lingkungan yang ada. Menurut Mappiare (dalam Siregar, 1993) anak terisolasi adalah anak yang jarang dipilih atau sering kali mendapat penolakan dari lingkungannya, salah satunya adalah kemampuan daya pikirnya yang rendah atau bodoh. Selanjutnya, Graham \& Stuart (dalam Hurlock, 1978) menjelaskan siswa terisolir adalah siswa yang mempunyai pengaruh sosial rendah dan penerimaan sosial rendah, sedangkan siswa popular adalah siswa-siswa yang memiliki pengaruh sosial dan penerimaan sosial yang tinggi.

Menurut Hurlock (1978), individu atau siswa yang terisolasi dari lingkungannya mempunyai ciri sebagai berikut yaitu: penampilan diri yang kurang menarik, kurang sportif, penampilan yang tidak sesuai dengan standar teman, perilaku yang menonjolkan diri, mengganggu orang lain, suka memerintah, tidak bekerjasama dan kurang bijaksana, kurangnya kematangan dalam hal pengendalian emosi, ketenangan, kepercayaan diri dan kebijaksanaan, mementingkan diri sendiri dan mudah marah, status sosio-ekonomis berada di bawah sosio-ekonomis kelompok, dan tempat yang terpencil dari kelompok (Hurlock, 1978). Selain itu, terdapat pula beberapa kesulitan seperti, kegagalan, kerugian, dan kemunduran yang terjadi pada siswa juga terdapat beberapa masalah siswa terisolir yang tak jauh berbeda dengan permasalahan self-esteem lainnya seperti, jarang masuk kelas karena 
malas untuk belajar dengan teman, tidak bekerjasama dan kurang bijaksana, putus asa ketika mendapat permasalahan, sering berpikir negatif (negative tingking) kepada, merasa tidak dihargai (rendah diri) dan yang lain sebagainya.

Hal ini disebabkan oleh rendahnya self-esteem yang menjadikan siswa tersebut merasa demikian. Maka, untuk meningkatkan self-esteem pertama kali dikenalkan oleh William James (1983-1890), seorang Psikolog berkebangsaan Amerika, menyebutkan bahwa perlu adanya pemahaman mengenai dirinya dan lingkungannya, melalui konseling eksistensialhumanistik. Rendahnya self-esteem sering dihubungkan dengan permasalahan gangguan mental seperti, depresi, kecemasan, frustasi, permasalahan belajar dan konflik (Sundari, 2005). Sebaliknya, tingginya self-esteem diyakini menjadi dasar bagi perkembangan mental yang sehat, kesuksesan, dan kehidupan yang efektif.

Rosenberg \& Owens mengidentifikasi bahwa karakteristik low self-esteem, mencakup hipersensitif, instability, ketidaksadaran diri, kurang percaya diri, takut mengambil resiko, mudah putus asa, pesimis, merasa kesepian dan terasing apabila individu memiliki nilai dan keyakinan yang realistis, serta merasa nyaman dengan dirinya sendiri. Harga diri itu memberdayakan, memberikan energi dan memotivasi. Hal ini mengilhami individu untuk mengambil kesenangan dan bangga dengan prestasi yang diraih oleh dirinya dan pada akhirnya bahwa mencapai kepuasan untuk dirinya (Santrock, 2010). Self-esteem dalam konteks Indonesia belum menjadi tema yang populer sebagaimana di Amerika, tapi bukan berarti Indonesia terlepas dari permasalahan self-esteem.

Lihatlah tema-tema pemberitaan yang selalu menjadi headline pada surat kabar dan televisi, seperti korupsi, suap, konsumsi narkoba, tawuran pelajar, kinerja buruk anggota dewan, seks bebas, rendahnya indeks prestasi nasional, kasus bunuh diri dan lain sebagainya. Selain itu, permasalahan spesifik muncul pada siswa di sekolah, seperti pergaulan bebas dikalangan remaja, pelacuran pada pelajar putri, mencontek untuk mendapatkan nilai bagus, merokok dan minuman keras, melakukan tindakan agresif untuk menunjukan otoritas dan eksistensi diri, motivasi belajar rendah, motivasi berprestasi rendah, dan lain sebagainya.

Sebagaimana hasil penelitian William et al. (1993) memberi pemikiran bahwa remaja yang memiliki self-esteem negatif adalah seseorang yang tidak percaya diri dengan bentuk tubuhnya. Hal ini dipertegas oleh penelitian yang dilakukan Wadden (2002) yang menyebutkan remaja dengan self-esteem negatif dapat memicu menderita penyakit kelainan makan, seperti bulimia dan anoreksia akibat dari obsesi menginginkan bentuk tubuh yang ideal. Maka untuk meningkatkan self-esteem pada siswa terisolir perlu adanya layanan konseling yang berpusat pada diri manusia atau melalui pendekatan eksistensial-humanistik. Dalam dunia pendidikan sudah tak asing lagi dengan adanya layanan konseling dengan berbagai pendekatannya, seperti konseling eksistensial-humanistik sendiri yang berfokus pada diri manusia dan aktualisasi diri.

Pendekatan ini mengutamakan suatu sikap yang menekankan pada pemahaman atas manusia. Konseling eksistensial-humanistik ini berpijak pada premis bahwa manusia tidak bisa lari dari kebebasan dan tanggung jawab yang saling berkaitan. Pendekatan eksistensialhumanistik dalam konseling menggunakan teknik yang bertujuan untuk mempengaruhi 
konseli. Pendekatan terapi eksistensial-humanistik bukan merupakan terapi tunggal, melainkan suatu pendekatan yang mencakup terapi-terapi yang berlainan yang kesemuanya berlandaskan konsep-konsep dan asumsi-asumsi tentang manusia (Corey, 2013).

Konseling Eksistensial-Humanistik ini berfokus pada diri manusia. Pendekatan ini mengutamakan suatu sikap yang menekankan pada pemahaman atas manusia. Berfokus pada sifat dari kondisi manusia yang mencakup kesanggupan untuk menyadari diri, bebas memilih untuk menentukan nasib sendiri, kebebasan dan tanggung jawab, kecemasan sebagai suatu unsur dasar, pencarian makna yang unik di dalam dunia yang tak bermakna, dan kecenderungan mengaktualisasikan diri. Pendekatan ini memberikan kontribusi yang besar dalam bidang psikologi, yakni tentang penekanannya terhadap kualitas manusia terhadap manusia yang lain dalam proses teurapeutik.

Berdasarkan hasil need assessment yang telah dilakukan dengan mengamati dan wawancara, serta informasi yang diperoleh melalui daftar cek masalah di Sekolah Menengah Atas menunjukan presentase tertinggi pada permasalahan yang terkait dengan rendahnya harga diri, seperti tidak percaya diri atau minder, sering menerima perlakukan yang melecehkan, merasa tidak mampu atau kesulitan pada beberapa mata pelajaran, takut menghadapi ulangan atau ujian, malas belajar, takut berbicara di depan kelas dan pada waktu diskusi, kesulitan berkomunikasi dengan teman, sering nyontek, gugup apabila menghadapi masalah, merasa kurang menarik bagi lawan jenis, tidak puas dengan kondisi tubuh, merasa tidak bahagia dengan kehidupan sekarang, dan merasa kesepian (sendirian) ditengah keramaian, merasa hidup sebatang kara. Keadaan diri yang seperti ini perlu mendapatkan penanganan yang tepat melalui layanan bimbingan dan konseling. Hal ini sesuai dengan Peraturan Menteri Pendidikan Nasional No. 27 Tahun 2008 mengenai Standard Kualifikasi Akademik dan Kompetensi Konselor dalam ABKIN (2011) bahwa tugas guru BK atau konselor adalah untuk mendukung perkembangan pribadi dari para peserta didik sesuai dengan kebutuhan, bakat, minat, dan kepribadian mereka, khususnya untuk membantu peserta didik memahami dan mengevaluasi diri sendiri. Dalam ruang lingkup yang lebih khusus tugas Guru BK atau Konselor diharapkan dapat ditempatkan dan mengembangkan kompetensinya bukan hanya di sekolah yang formal tetapi di lingkungan yang dapat membantu melayani perkembangan untuk meningkatkan self-esteem (harga diri) dan mengembangkan potensi anak yang terisolir.

\section{METODE PENELITIAN}

Jenis Penelitian yang digunakan pada penelitian ini adalah jenis kualitatif. Menurut Moelong (2013) penelitian kualitatif adalah penelitian yang bermaksud untuk memahami fenomena tentang apa yang dialami oleh subjek penelitian misalnya perilaku, persepsi, motivasi, dan tindakan secara holistik, yang dilakukan dengan cara deskripsi dalam bentuk kata-kata dan bahasa pada suatu konteks khusus yang alamiah dan dengan memanfaatkan berbagai metode ilmiah. Bentuk penelitian yang akan digunakan dalam penelitian ini adalah penelitian deskriptif kualitatif. 
Analisis data dalam penelitian kualitatif adalah proses mencari dan menyusun secara sistematis data yang diperoleh dari hasil wawancara, catatan lapangan, dan dokumentasi, dengan cara mengorganisasikan data kedalam kategori, menjabarkan ke dalam unit-unit, melakukan sintesa, menyusun ke dalam pola, memilih mana yang penting dan yang akan dipelajari, dan membuat kesimpulan sehingga mudah dipahami oleh diri sendiri maupun orang lain. Analisis data penelitian kualitatif dilakukan sejak sebelum memasuki lapangan, selama di lapangan, setelah selesai di lapangan.

Dalam proses analisis data peneliti menggunakan model Miles \& Hubeman (Sugiyono, 2012), yang dijelaskan sebagai berikut.

1. Mereduksi Data berarti merangkum, memilih hal-hal yang pokok, memfokuskan pada hal-hal yang penting, dicari tema dan polanya dan membuang yang tidak perlu. Dalam hal ini peneliti mencoba memilih data yang relevan dengan implementasi konseling eksistensial-humanistik dalam meningkatkan self-esteem pada siswa terisolir.

2. Penyajian data dilakukan dalam bentuk uraian singkat, tabel, hubungan antar kategori, dan sejenisnya. Penyajian data yang paling sering digunakan dalam penelitian kualitatif adalah dengan teks yang bersifat naratif. Berdasarkan hal tersebut, setelah peneliti mendapatkan data mengenai implementasi konseling eksistensial-humanistik dalam meningkatkan self-esteem pada siswa terisolir, maka data tersebut disusun dan disajikan dalam bentuk narasi, verbatim, tabel, dan sebagainya.

3. Penyimpulan atas apa yang disajikan, pengambilan kesimpulan dengan menghubungkan tema sehingga memudahkan untuk menarik kesimpulan. Kesimpulan awal yang dikemukakan masih bersifat sementara, dan akan berubah bila tidak ditemukan buktibukti yang kuat yang mendukung pada tahap pengumpulan data berikutnya. Tetapi apabila kesimpulan yang dikemukakan pada tahap awal, didukung oleh bukti-bukti yang valid dan konsisten saat peneliti kembali ke lapangan mengumpulkan data, maka kesimpulan yang dikemukakan merupakan kesimpulan yang kredibel.

\section{HASIL DAN PEMBAHASAN}

\section{Metode Dalam Meningkatkan Self-Esteem Pada Siswa Terisolir di Kelas XI SMAN 1 Lemahabang}

Dari hasil wawancara dan observasi yang telah dilakukan metode, dalam meningkatkan self-esteem pada siswa terisolir di kelas XI SMAN 1 Lemahabang yang diterapkan oleh guru BK kelas XI yaitu pemberian dukungan sosial (social support) untuk meningkatkan self-esteem didasari anggapan bahwa self-esteem dipengaruhi oleh dukungan sosial. Intervensi yang termasuk dalam kategori ini adalah konseling teman sebaya, seperti yang dikemukakan oleh Frey \& Carlock (dalam Wikan, 2012) bahwa pemberian dukungan sosial disusun untuk membantu tiap-tiap klien yang terlibat untuk untuk memperkecil jarak antara kondisi diri saat ini (actual self) dengan kondisi diri yang diinginkan (ideal self). Intervensi ini dilakukan dengan cara melibatkan significant other dan pemberian umpan balik positif terhadap klien. Selain itu, intervensi lain yang termasuk dalam kategori ini adalah mengubah pola asuh orang tua (parenting). 
Menurut pendapat Pak Diki selaku guru BK kelas XI di SMAN 1 Lemahabang tujuan dari metodenya yaitu:

"Dukungan sosial atau intervensi yang termasuk dalam metode yang dilakukan yaitu konseling teman sebaya, yang mana teman-teman kelas membantu siswa yang terisolir tersebut untuk sama-sama berkembang bersama dengan lingkungan yang sehat. Hal itu berguna agar di kelas yang terdapat siswa terisolir itu dapat merasa dihargai dan menciptakan kelas kondusif, yang mana di kelas itu memiliki lingkungan yang melibatkan siswa terisolir secara positif, saling pengertian satu dengan lainnya, menyediakan atau memberikan informasi dan aturan yang mewakili harapan yang sesuai dengan kemampuan siswa terisolir tersebut".

Intervensi cognitive-behavior Guindon (dalam Wikan, 2012) menyatakan bahwa strategi-strategi cognitive-behavior merupakan strategi yang paling banyak digunakan dalam menangani self-esteem karena terbukti efektif dalam menangani individu berbagai usia. Perubahan self-esteem dapat terjadi apabila individu mengalami intervensi kognitif yang disusun untuk menata ulang (restructuring) proses evaluasi diri klien. Upaya yang dilakukan guru BK dalam memberikan intervenesi cognitive-behavior kepada siswasiswa menurut Pak Diki:

"Beberapa upaya yang dilakukan untuk memberikan intervensi cognitive-behavior dengan cara disusun kembali atau menata ulang pemikirannya yang cenderung pada arah pesimis dan negatif pada orang lain, dan dilakukan pula proses evaluasi diri siswa terisolir, nah selain itu siswa juga di sadarkan tentang dirinya sebagai anak yang disayangi oleh orang tuanya, yang memiliki harapan besar pada dirinya, maka siswa pun merasa memiliki tanggung jawab atas kehidupan yang dijalaninya”.

Metode lainnya yaitu pemantapan fisik (physical fitness), yang didasari oleh pemikiran bahwa dengan memiliki kondisi tubuh yang prima atau menguasai keterampilan olahraga tertentu, remaja (baik laki-laki maupun perempuan) akan meningkatkan self-esteem, terutama yang berkaitan dengan aspek body image. Pada remaja laki-laki, intervensi ini lebih bermanfaat karena kompetensi fisik memiliki peranan yang lebih besar untuk meningkatkan self-esteem laki-laki. Sementara itu, yang dilakukan untuk memberikan pemantapan fisik siswa terisolir seperti yang dipaparkan oleh Pak Diki yaitu:

"Uuntuk siswa terisolir yang memiliki permasalahan akan fisiknya, yang dilakukan itu dengan menggunakan motivasi hidup sehat atau bisa termasuk juga dalam pemantapan fisik dimana terdapat intervensi yang didasari oleh pemikiran bahwa dengan memiliki kondisi tubuh yang sehat atau menguasai keterampilan olah raga tertentu, siswa (baik laki-laki maupun perempuan) akan meningkat self-esteemnya, terutama yang berkaitan dengan aspek body image".

Strategi lainnya yang telah terbukti efektif meningkatan self-esteem adalah intervensi spesifik yang tergantung pada populasi yang dituju, seperti Eye-Movement, Desentization and Reprocessing (EMDR) yang ditujukan khusus untuk meningkatkan 
self-esteem anak-anak dengan masalah perilaku. Selain iu ada juga Process Based Forgiveness yang menggunakan berbagai strategi, seperti Reality Therapy, Solution Focused, Narrative Therapy, Creative Arts dan Play Therapy (Wikan, 2012). Dalam hal ini metode yang dapat dilakukan menurut pendapat Pak Diki:

"Untuk strategi lainnya yang dilakukan mengalir saja dalam proses konseling dan tidak terlalu di rencanakan ya, karena biasanya strategi ini muncul ketika memang dalam proses konseling itu sendiri siswa tidak ada perubahan lebih baik atau kemajuan dalam mengatasi masalahnya, jadi munculah ide-ide lain yang mampu mengatasi masalah dan bertujuan untuk menjadikan siswa tersebut supaya mau menjadi lebih baik, seperti dengan pendekatan eksistensial-humanistik hal ini termasuk dalam strategi lainya, dimana siswa terisolir tersebut diberi pemahaman tentang kesadaran dirinya sebagai manusia, yang memiliki kekurangan dan juga potensi yang dimilikinya, maka siswa tersebut perlu menciptakan suatu makna bahwa hidup perlu dilaluinya dengan semangat, dan menghargai diri sendiri untuk mewujudkan harapan yang dia inginkan."

Berdasarkan hasil wawancara dan observasi di atas, metode yang digunakan dalam meningkatkan self-esteem pada siswa terisolir di kelas XI SMAN 1 Lemahabang, dilakukan dengan menggunakan beberapa metode, antara lain: 1) pemberian dukungan sosial (social support); 2) intervensi cognitive-behavior therapy; 3) pemantapan fisik (physical fitness); dan 4) strategi lain, termasuk didalamnya konseling eksistensialhumanistik. Metode-metode tersebut memberikan perubahan perilaku siswa terisolir yang lebih baik, dan mampu memotivasi siswa untuk dapat membaur dengan lingkungannya.

\section{Implementasi Konseling Eksistensial-Humanistik dalam Meningkatkan Self-Esteem Pada Siswa Terisolir di Kelas XI SMAN 1 Lemahabang}

Implementasi konseling eksistensial-humanistik dalam meningkatkan self-esteem pada siswa terisolir di kelas XI SMAN 1 Lemahabang, dalam pelaksanaannya menggunakan konsep dari Gerald Corey (2013), yaitu sebagai berikut.

a. Kesadaran diri

Manusia memiliki kesanggupan untuk menyadari dirinya sendiri, suatu kesanggupan yang unik dan nyata yang memungkinkan manusia mampu berpikir dan memutuskan. Semakin kuat kesadaran diri itu pada seseorang, maka akan semakin besar pula kebebasan yang ada pada orang itu. Kesanggupan untuk memilih alternatifalternatif yakni memutuskan secara bebas di dalam kerangka pembatasnya adalah suatu aspek yang esensial pada manusia.

b. Kebebasan, tanggung jawab, dan kecemasan

Kesadaran atas kebebasan dan tanggung jawab dapat menimbulkan kecemasan yang menjadi atribut dasar pada manusia. Kecemasan eksistensial juga bisa diakibatkan oleh kesadaran atas keterbatasannya dan atas kemungkinan yang tak terhindarkan untuk mati. Kesadaran atas kematian memiliki arti penting bagi kehidupan individu 
sekarang, sebab kesadaran tersebut menghadapkan individu pada kenyataan bahwa dirinya memiliki waktu yang terbatas untuk mengaktualkan potensi-potensinya.

c. Penciptaan makna manusia itu unik

Hal ini dalam artian bahwa individu berusaha untuk menemukan tujuan hidup dan menciptakan nilai-nilai yang akan memberikan makna bagi kehidupan. Pada hakikatnya manusia memiliki kebutuhan untuk berhubungan dengan sesamanya dalam suatu cara yang bermakna, sebab manusia adalah makhluk rasional. Kegagalan dalam menciptakan hubungan yang bermakna dapat menimbulkan kondisi-kondisi keterasingan dan kesepian. Manusia juga berusaha untuk mengaktualkan diri yakni mengungkapkan potensi-potensi manusiawinya sampai taraf tertentu.

Anak terisolasi adalah anak yang jarang dipilih atau sering kali mendapat penolakan dari lingkungannya, salah satunya adalah kemampuan daya pikirnya yang rendah atau bodoh. Selain itu, dapat pula disimpulkan bahwa siswa terisolasi dari lingkungannya mempunyai ciri sebagai berikut, penampilan diri yang kurang menarik, kurang sportif, penampilan yang tidak sesuai dengan standar teman, perilaku yang menonjolkan diri, mengganggu orang lain, suka memerintah, tidak bekerjasama dan kurang bijaksana, kurangnya kematangan dalam hal pengendalian emosi, ketenangan, kepercayaan diri dan kebijaksana, mementingkan diri sendiri dan mudah marah, status sosioekonomis berada di bawah sosio-ekonomis kelompok, tempat yang terpencil dari kelompok (Hurlock, 1978).

Hal ini tidak lain disebabkan oleh low self-esteem (harga diri rendah) yang menjadikan siswa tersebut merasa demikian. Maka untuk meningkatkan self-esteem pada siswa terisolir dilakukan konseling yang berpusat pada diri manusia atau melalui pendekatan eksistensial-humanistik. Pendekatan ini mengutamakan suatu sikap yang menekankan pada pemahaman atas manusia. Oleh sebab itu, implementasi konseling eksistensial-humanistik sangat diperlukan dan diterapkan untuk meningkatkan self-esteem pada siswa terisolir dengan tujuan memperoleh keberhasilan pada perubahan perilaku siswa menjadi lebih baik dari aspek lingkungan sekolah, rumah, dan pola pikirnya. Siswa terisolir yang memiliki self-esteem rendah di kelas XI SMAN 1 Lemahabang semester ganjil berjumlah 4 siswa.

Dalam penelitian ini peneliti mengambil dari masing-masing jurusan yakni 2 siswa jurusan IPS dan 2 siswa jurusan IPA dengan jumlah seluruhnya 4 siswa terisolir untuk dijadikan subjek fokus, yakni DF, HBL, W dan IS.

1. Temuan Pada Subjek Primer Pertama

Df adalah anak terakhir dari tiga bersaudara yang berjenis kelamin perempuan. Kebutuhan Df selalu terpenuhi oleh orangtuanya karena kedua orangtuanya bekerja, dari kedua orang tuanya Df paling dekat dengan Ayahnya. Df bertempat tinggal di Kanci Wetan, Cirebon Timur. Df memiliki kesulitan untuk berkomunikasi dengan teman-teman lainnya terutama saat di kelasnya sendiri, hingga ia sering tidak masuk 
kelas dan enggan berbaur dan akhirnya Df merasa diasingkan atau terisolir. Faktor penyebab ia merasa terisolir ialah, self-esteem (harga diri) rendah yang menganggap dirinya tidak berarti, dan hanya membuat malu teman-temannya ketika bersamanya, takut untuk mencoba berbaur dan bersosialisasi, dan kurangnya motivasi untuk lebih percaya diri.

Hasil wawancara dari Df, dapat disimpulkan bahwa faktor utama Df merasa terisolir karena self-esteem yang rendah terhadap lingkungannya. Sebenarnya Df merupakan siswa yang memiliki potensi bermain volly, terlebih lagi Df memiliki keinginan untuk bergabung dengan teman-temannya sebelum ia di tolak. Namun karena teman-teman dalam lingkungan yang tidak mendukung dan mengarah pada perilaku yang acuh tak acuh, mengakibatkan Df merasa diasingkan dan terisolir. Df yang merasa terisolir, menjadi takut untuk membaur dilingkungannya dan malas untuk berangkat sekolah yang akhirnya menyebabkan ia memiliki absen (alpa) yang tinggi pada kehadiranya di sekolah. Menurut Df selama mengikuti proses konseling, Df dapat mengerti tentang kesadaran diri, dan memahami kebebasan, tanggung jawab dan kecemasan yang terjadi pada masalah Df. Setelah Df melakukan konseling, Df mampu menentukan keputusan atas permasalahan yang ada dengan penciptaan makna.

Setelah mendapatkan jawaban dari Df tentang implementasi konseling eksistensial-humanistik di kelas XI SMAN 1 Lemahabang, dapat disimpulkan bahwa terdapat perubahan perilaku Df ke arah yang lebih baik. Dari kegiatan konseling pendekatan eksistensial-humanistik tersebut, Df jadi lebih optimis lagi dan berusaha membaur dan juga berfikir positif terhadap teman-teman lainnya sebagai cara untuk meningkatkan self-esteem pada dirinya.

2. Temuan Pada Subjek Primer Kedua

HBL adalah siswa yang berasal dari kelas XI IPS 4, dan bersekolah di SMAN 1 Lemahabang, HBL pada awalnya adalah siswa pindahan dari SMAN 1 Kota Cirebon, dan pindah ke SMAN 1 Lemahabang pada semester kedua di kelas 10. HBL mengalami masalah pada awal masuk hingga sekarang akhir semester kelas 11. Awalnya ia terlambat datang ke Sekolah, hingga akhirnya ia memutuskan kembali pulang ke Rumah, beberapakali ia lakukan akhirnya ia sering terlambat dan memilih untuk bolos Sekolah. Hal ini semakin menjadi-jadi ketika HBL memiliki permasalahan dengan lingkungan di kelas yakni teman-temannya karena HBL memang jarang masuk dan kurang bersosialisasi, dan saat ada tugas kelompok HBL lebih set berkontribusi, ia menjadi malas di kelas dan malas untuk berangkat sekolah, karena selain ia tidak memiliki teman akrab dikelasnya, HBL lebih tertarik untuk main diluar Sekolah, yang sekarang sedang ia sukai adalah Club Motor King, yang mana HBL rasa mendapat kenyamanan di dalam Club ini.

Faktor penyebab HBL merasa terisolir ialah, karena dia kecewa pada temantemannya karena sikap mereka yang kurang sopan tidak sesuai dengan yang diharapkan oleh HBL, dan HBL pun menarik diri dari teman-temannya, hingga 
akhirnya ia merasa diasingkan dan terisolir. Adapun beberapa kemungkinan penyebab ia merasa terisolir ialah: selfesteem (harga diri) rendah, idealisme yang terlalu tinggi, kurangnya motivasi untuk mau membaur dan menerima teman-temannya.

Setelah mengetahui yang terjadi pada HBL, dapat disimpulkan bahwa faktor utama HBL merasa terisolir karena self-esteem yang rendah terhadap lingkungannya. Sebenarnya HBL merupakan siswa yang memiliki kepedulian dan tidak suka dengan pertengkaran dan tingkah laku yang kasar. Namun karena HBL merasa kecewa pada teman-teman dalam lingkungannya yang kadang sering berbicara kasar, mengakibatkan HBL menarik diri dan merasa diasingkan atau terisolir. HBL yang merasa terisolir, menjadi enggan untuk membaur dilingkungannya dan malas untuk berangkat sekolah yang akhirnya menyebabkan ia memiliki absen (alpa) yang tinggi pada kehadiranya di kelasnya. Setelah ia tidak berangkat beberapakali, dan pernah bolos HBL mendapatkan arahan untuk mengikuti konseling dengan guru BK kelas XI di SMAN 1 Lemahabang. HBL sudah mengikuti proses konseling di Sekolah.

Selama HBL mengikuti proses konseling, layanan dan arahan yang di berikan kepada HBL dalam proses konseling, HBL dapat mengerti tentang kesadaran diri, dan memahami kebebasan, tanggung jawab dan kecemasan yang terjadi pada masalah yang dialaminya, dan mampu menentukan keputusan atas permasalahan yang ada dengan penciptaan makna. Setelah mendapatkan jawaban dari HBL tentang implementasi konseling eksistensial-humanistik di kelas XI SMAN 1 Lemahabang, dapat disimpulkan bahwa terdapat perubahan perilaku HBL ke arah yang lebih baik. Dari kegiatan konseling pendekatan eksistensial-humanistik tersebut, HBL jadi lebih optimis dan berusaha membaur dan juga berfikir positif terhadap teman-teman lainnya sebagai cara untuk meningkatkan self-esteem pada dirinya.

3. Temuan Pada Subjek Primer Ketiga

W adalah siswi perempuan, yang berasal dari kelas XI IPS 3, dan bersekolah di SMAN 1 Lemahabang, W mengalami masalah pada awal semester kelas 11. Awalnya ia pernah tidak berangkat sekolah karena sakit berkepanjangan hinga pada saat ia tidak masuk kelas W merasa tidak dipedulikan dan tidak diberi kabar mengenai tugas kelas, dan teman-teman sering memojokan karena ia tidak memakai HP Android, hingga akhirnya W merasa teman-temannya memojokannya terutama ketika membahas halhal yang berupa materi, karena $\mathrm{W}$ tergolong dalam keluarga yang pas-pas an. Hal ini semakin terasa ketika W memiliki permasalahan dengan teman-temannya dan saat ada pengumuman tugas $\mathrm{W}$ tidak mendapat kabar karena dia tidak memakai what's ups, dan ia selalu mendapat respon yang memojokan dari teman-temannya, ketika tidak ikut mempunyai WA akibat dari keterbatasannya, hal ini menjadikan $\mathrm{W}$ merasa terisolir dan diasingkan oleh teman-temannya.

Faktor penyebab ia merasa terisolir ialah, W sering mendapat perilaku kurang baik dari teman-temannya dan sering dipojokan karena kekurangan materi, akhirnya menjadi malas untuk peduli dengan yang lain dan malas belajar dengan temannya, hingga akhirnya ia merasa diasingkan dan terisolir. Adapun beberapa kemungkinan 
penyebab ia merasa terisolir ialah karena, self-esteem (harga diri) rendah, Sulit untuk menerima perlakuan orang lain dan kurangnya motivasi untuk lebih percaya diri. Setelah mengetahui permasalahan $\mathrm{W}$, dapat disimpulkan bahwa faktor utama $\mathrm{W}$ merasa terisolir karena self-esteem yang rendah terhadap lingkungannya. Sebenarnya W merupakan siswa yang aktif dan mau bersosialisasi.

Namun karena W memiliki keterbatasan secara materil, mengakibatkan W menarik diri dan merasa di asingkan atau terisolir. Lalu W yang merasa terisolir, menjadi enggan untuk membaur dilingkungannya dan malas untuk berangkat sekolah juga pernah bolos sekolah, yang akhirnya menyebabkan ia memiliki absen (alpa) yang tinggi pada kehadiranya di kelasnya. Setelah ia tidak berangkat beberapakali, dan pernah bolos W mendapatkan arahan untuk mengikuti konseling dengan guru BK kelas XI di SMAN 1 Lemahabang.

Selama $\mathrm{W}$ mengikuti proses konseling, $\mathrm{W}$ dapat mengerti tentang kesadaran diri, dan memahami kebebasan, tanggung jawab dan kecemasan yang terjadi pada masalahnya, dan mampu menentukan keputusan atas permasalahan yang ada dengan penciptaan makna. Setelah mendapatkan jawaban dari W tentang implementasi konseling eksistensial-humanistik di kelas XI SMAN 1 Lemahabang, dapat disimpulkan bahwa terdapat peningkatan self-esteem $\mathrm{W}$ ke arah yang lebih baik. Dari kegiatan konseling pendekatan eksistensialhumanistik tersebut, $\mathrm{W}$ jadi lebih optimis lagi dan berusaha membaur dan juga berfikir positif terhadap teman-teman lainnya sebagai cara untuk meningkatkan self-esteem pada dirinya.

4. Temuan Pada Subjek Primer Keempat

IS adalah siswa laki-laki yang berasal dari kelas XI IPA 1, IS pada awalnya adalah siswa yang memiliki banyak teman dan mudah bergaul dalam kesehariannya, hal ini ditunjukan dengan kegiatannya di APK atau ikut serta dalam berbagai kegiatan, ia termasuk siswa yang rajin masuk kelas. IS mengalami masalah pada akhir semester ganjil kelas 11. Awalnya ia pernah tidak berangkat sekolah karena sakit, kecapean setelah mengikuti kegiatan ekstrakulikuker di sekolah hinga pada saat ia tidak masuk kelas IS merasa tidak dipedulikan dan tidak diberi kabar mengenai tugas kelas, hingga akhirnya terjadi kesalah pahaman dengan teman-teman dan IS merasa temantemannya egois ketika ada tugas kelompok.

Hal ini semakin memuncak ketika IS memiliki permasalahan dengan temantemannya dan saat ada tugas kelompok IS lebih set berkontribusi, ia menjadi malas dikelas dan malas untuk berangkat sekolah, karena selain ia harus prihatin mengenai keadaan kemampuan memiliki keuangan yang seadanya ia selalu mendapat respon yang kurang enak dari temantemannya, ketika tidak ikut membayar infak yang dilaksanakan hari jumat, hal ini menjadikan IS merasa asing dan terisolir oleh temantemannya. Faktor penyebab ia merasa terisolir ialah, IS sering mendapat perilaku kurang baik dari teman-temannya dan menjadi malas untuk peduli dengan yang lain atau belajar dengan teman kelompoknya, hingga akhirnya ia merasa diasingkan dan terisolir. Adapun beberapa kemungkinan penyebab ia merasa terisolir ialah, self- 
esteem (harga diri) rendah, tidak peduli lagi dengan lingkungannya, kurangnya motivasi untuk lebih percaya diri.

Setelah mengetahui permasalahan dari IS, dapat disimpulkan bahwa faktor utama IS merasa terisolir karena self-esteem yang rendah terhadap lingkungannya. IS merupakan siswa yang mudah bergaul dan tidak suka di ganggu. Namun karena IS merasa terpojokan oleh temanteman dalam lingkungannya yang kadang sering memaksa IS untuk bayar iuran meskipun IS tidak punya uang, akhirnya IS menarik diri dan merasa di asingkan atau terisolir dari teman-temannya. IS merasa terisolir, menjadi enggan untuk kembali bersatu dengan teman-temannya dikelas dan malas untuk berangkat sekolah yang akhirnya menyebabkan ia memiliki absen (alpa) yang tinggi pada kehadiranya di kelasnya.

IS mendapatkan arahan untuk mengikuti konseling dengan guru BK kelas XI di SMAN 1 Lemahabang. Selama IS mengikuti proses konseling, IS dapat mengerti tentang kesadaran diri, dan memahami kebebasan, tanggung jawab dan kecemasan yang terjadi pada masalah IS, dan IS mampu menentukan keputusan atas permasalahan yang dihadapinya dengan memberikan penciptaan makna. Setelah mendapatkan jawaban dari IS tentang implementasi konseling eksistensialhumanistik di kelas XI SMAN 1 Lemahabang, dapat disimpulkan bahwa terdapat perubahan perilaku IS ke arah yang lebih baik. Dari kegiatan konseling pendekatan eksistensial-humanistik tersebut, IS jadi lebih optimis lagi dan berusaha membaur dan juga berfikir positif terhadap teman-teman lainnya sebagai cara untuk meningkatkan self-esteem pada dirinya.

Berdasarkan hasil wawancara yang dilakukan dengan Guru BK, DF, HBL, W dan IS, maka terdapat hasil positif dari implementasi konseling eksistensial-humanistik dalam meningkatkan self-steem pada siswa terisolir, dalam hal ini terdapat perbedaan pada penerapan konseling. DF tipikal siswi yang tertutup ia tidak mudah untuk mengungkapkan permasalahannya sehingga dalam pelaksanaan konseling Guru BK berusaha lebih dalam saat menggali akar permaslahannya. Sementara itu HBL merupakan tipikal siswa yang idealis dimana segala sesuatunya harus sesuai dengan yang HBL inginkan, untuk pelaksanaan konseling pada HBL guru BK memberikan pemahaman tentang kesadaran diri yang bertujuan agar HBL dapat mengerti dirinya dan lingkungannya. Selain itu siswi yang bernama W merupakan tipikal siswi yang terbuka, maka dalam penerapan konselingnya dapat dikatakan mudah dalam melaksanakannya. Lalu IS juga termasuk pada tipikal siswa yang terbuka dalam pelaksanaan konseling IS akan sangat mudah untuk mencerna dan akhirnya mampu menceritakan permasalahannya. 


\section{SIMPULAN}

Metode dalam meningkatkan self-esteem pada siswa terisolir di kelas XI SMAN 1 Lemahabang yang dilakukan oleh guru BK di kelas XI terhadap siswa terisolir, sudah bisa dikatakan sesuai dengan teori dalam peningkatan self-esteem. Oleh karena itu terdapat beberapa metode yang telah dilakukan oleh guru BK itu sendiri dalam meningkatkan selfesteem pada siswa terisolir di kelas XI SMAN 1 Lemahabang, beberapa metode tersebut yaitu: (1) pemberian dukungan sosial (social support), (2) intervensi cognitive-behavior, (3) pemantapan fisik, dan (4) strategi lainnya (konseling pendekatan eksistensial-humanistik). Implementasi konseling eksistensial-humanistik dalam meningkatkan self-esteem pada siswa terisolir di kelas XI SMAN 1 Lemahabang, dilakukan melalui layanan konseling individual yang bertujuan mengarahkan atau membimbing menggunakan pendekatan teori eksistensialhumanistik dengan menerapkan kesadaran diri, kebebasan, tanggung jawab, dan penciptaan makna. Berdasarkan hasil wawancara yang dilakukan kepada DF, HBL, W dan IS, terdapat hasil yang berbeda dari implementasi konseling eksistensial-humanistik dalam meningkatkan self-steem pada siswa terisolir, dalam hal ini terdapat perbedaan pada penerapan konseling, yang disesuaikan dengan tipe kepribadian dan watak dari masingmasing konseli.

\section{DAFTAR PUSTAKA}

Ali, M. (2015). Psikologi Remaja. Jakarta: PT. Bumi Aksara.

Anwar, M. F. (2015). Landasan Bimbingan dan Konseling Islam. Yogyakarta: Deepublish.

Arikunto, S. (2010). Prosedur Penelitian. Jakarta: Rineka Cipta. Bagus,

Bungin, B. (2007). Metode Penelitian Kualitatif. Bandung: PT Rineka Cipta.

Clemes, H., Reynold B., \& Clark. (2012). Bagaimana Kita Meningkatkan Harga Diri Remaja. Terjemahan oleh Dra. Med. Meitasari Tjandrasa. Tangerang Selatan: Binarupa Aksara Publisher.

Corey, G. (2013). Teori dan Peraktek Konseling \& Psikoterapi. Bandung: Refika Aditama.

Dariyo, A. (2006). Psikologi Perkembangan Anak Tiga Tahun Pertama. Bandung: Refika Aditama.

Desmita. (2010). Psikologi Perkembangan. Bandung: PT. Remaja Rosdakarya.

Erman A. \& Prayitno. (1999). Dasar-Dasar Bimbingan dan Konseling. Jakarta: PT. Rineka Cipta.

Gunarsa, S. dan Yulia. (1985). Psikologi Perkembangan Anak dan Remaja. Jakarta: PT BPK Gunung Mulia.

Hurlock, E. B. (1978). Perkembangan Anak Jilid 1. Jakarta: Erlangga.

Juntika N. A. (2014). Bimbingan \& Konseling dalam Berbagai Latar Kehidupan. Bandung: Refika Aditama. 
Latipun. (2003). Psikologi Konseling. Malang: UMM Press.

Masleham. (1996). Teknik Konseling Individual. Jombang : Cv saudara.

Moleong, L. J. (2013). Metodologi Penelitian Kualitatif, Cetakan ke-21. Jakarta: Rineka Citra.

Mulyana, D. (2013). Metode Penelitian Kualitatif. Bandung: PT. Remaja Rosdakarya.

Santrock, J. W. (2010). Psikologi Pendidikan. Jakarta: Kencana.

Sugiyono. (2012). Metode Penelitian Kuantitatif, Kualitatif, $R$ dan D, Cet. 10. Bandung: Alfabeta.

Usman, N. (2002). Konteks Implementasi Berbasis Kurikulum. Jakarta: PT. Raja Grafindo Persada.

Wikan, P. L. (2012). Meningkatkan self-esteem Melalui Metode Self-Intruction. Psi UI.

Willis, S. (2014). Konseling Individual Teori dan Praktek. Bandung: Alfabeta. 